\title{
REDEFINITION OF THE GENERA MALAXIS SOL. EX SW. AND MICROSTYLIS (NUTT.) EATON (ORCHIDACEAE, EPIDENDROIDEAE)
}

\author{
DARIUSZ L. SZlachetKo, HANNA B. MARGOŃSKA* \\ Department of Plant Taxonomy and Nature Conservation \\ Gdańsk University \\ Al. Legionów 9, 80-441 Gdańsk, Poland \\ *e-mail: dokhbm@univ.gda.pl
}

(Received: January 6, 2006. Accepted: March 24, 2006)

ABSTRACT

A new definition of the genera Malaxis Sol. ex Sw. and Microstylis (Nutt.) Eaton is presented. The genera are briefly described and illustrated. A list of Microstylis species is added. Four new nomenclatural combinations are proposed.

KEY WORDS: Malaxis, Malaxidinae, Microstylis, Orchidaceae, systematic, taxonomy.

The subtribe Malaxidinae includes genera with minute or medium-sized flowers mostly, usually inconspicuously coloured. The representatives of this group occur on all continents, except Antarctica. Peculiarly abundant in species of Malaxidinae are SE Asia, New Guinea and Pacific islands and also New World. Until quite lately most of the species were included in two cosmopolitan and highly polymorphic genera Malaxis Sol. ex Sw. and Liparis L.C.Rich.

The genus Malaxis was described by Solander in Swartz's paper in 1788. At first it embraces 2 species from Jamaica $-M$. spicata and $M$. umbelliflora, both found by Solander and described in the aforementioned work of Swartz. Nuttall (1818) divided the genus Malaxis into two subgenera: Malaxis and Microstylis. The first one included the sole species M. paludosa (L.) Sw., the second one - all other, together with tropical species and type species of that genus. Eaton (1822) gave the generic rank to the subgenus Microstylis, choosing as the type of the genus Microstylis ophioglossoides (Willd.) Eaton. This species is now treated as a synonym of Malaxis unifolia Michx. Ridley (1888) accepted Eaton's concept of both genera.

Malaxis paludosa, however, cannot be the lectotype of the genus, as it is at variance with the Art. 10.2 of ICBN (Greuter et al. 2000). The original description of the genus Malaxis (Swartz 1788) did not include this species. As a valid generitype must be treated Malaxis spicata chosen by Britton and Brown (1913).

The latter studies proved that Eaton's (1822) and Ridley's (1888) conception was wrong. In 1891 Kuntze created a new genus Hammarbya for Malaxis paludosa, whereas Microstylis was recognized as a synonym of the earlier one and also the preferencial genus Malaxis (ICBN Art. 11.3, Greuter et al. 2000). This concept has been adopted by most of the later researchers (e.g.: Holttum 1957; Comber 1990, 2001; Seidenfaden 1978, 1992a; Seidenfaden and Wood 1992; Wood and Cribb 1994). However, already Seidenfaden (1978) and some other scientists (Hill and Blaxell 1985) clearly suggested the polymorphic character of this genus.

Our studies of the generative structures of Epidendroideae (Szlachetko 1995; Szlachetko and Margońska 2005), especially Malaxis proved how strongly the taxon is polymorphic, so we proposed to separate a few genera (Crepidium Bl. emend Szlach., Glossochilopsis Szlach., Kornasia Szlach., Lisowskia Szlach., Oberonioides Szlach., Siedenfia Szlach., Tamayorkis Szlach., Szlachetko 1995; Pseudoliparis Finet emend Szlach. \& Marg., Szlachetko and Margońska 1999; Saurolophorkis Marg. \& Szlach., Margońska and Szlachetko 2001; Siedenforchis Marg., Margońska in press).

While reviewing the Malaxis materials from the New World we noticed distinct differences in the gynostemium structure in local representatives of the genus (Szlachetko and Margońska 2002). Comparing them to the type species of the genera Malaxis and Microstylis induced us to recognize them as separate taxa, which are different in the structure of gynostemium and pollinia.

Rafinesque proposed Achroanthes in 1808 with no description and only sole species Achroanthes unifolia (Michx.) Raf. (Microstylis unifolia (Michx.) Britton). The description of Achroanthes was published by Rafinesque (1819) only ten years later (in J. Phys. 89: 261, 1819). 
However the older name for the group of the orchids is Achroanthes Rafin., but the name Microstylis has priority over Achroanthes because it is nom. \& orth. consere. (ICBN Art. 14, Greuter et al. 2000).

Malaxis Sol. ex Sw.

Prod. Veg. Ind. Occ. 119. 1778.

- Generitype: Malaxis spicata Sol. ex Sw.

Inflorescence very often subumbellate. Gynostemium usually very short and massive, erect. Column part vestigial, occasionally longer (M. salazarii (Catling) Szlach. \& Marg.), with 2 apical, obscure, wing-like staminodia on both anther sides. Anther base much below the stigma base. Anther erect, firmly and widely joined with the gynostemium, transversely ellipsoid, 2-chambered, chambers opening apically, widely spread apically, connate basally. Filament incorporated into the column part. Connective wide and short, relatively thick. Pollinia 4, in two pairs, unequal in size and form, clavate, hard, the inner pair usually much smaller, lamellar, strongly laterally compressed. Dorsal clinandrium obscure. Stigma ventral, transverselly elliptic to oblong, flat or slightly concave at the base. Rostellum erect, obscurely 3-lobed, truncate or with a shallow sinus between both lateral lobes, each of the lateral lobe terminated with viscidium. Viscidia two, small, delicate, membranous (Fig. 1).

\section{Microstylis (Nutt.) Eaton}

Man. Bot., ed. 3: 353. 1822.

- Generitype: Microstylis unifolia Michx.

Inflorescence elongate, cylindrical. Gynostemium rather short to elongate, slender, erect. Column part nearly as long as the anther or longer. Anther base below the stigma base, erect, hardly motile, dorsiventrally flattened, subquadrate to elliptic-ovate, 2-chambered, chambers opening ventrally, parallel. Filament incorporated into the dorsal clinandrium. Connective covering both locules, rather thick. Pollinia 4 , in two pairs, joined together apically, unequal in size, more or less clavate, elliptic to slightly laterally compressed in cross-section, formed from tightly packed pollen grains. Caudiculae absent. Dorsal clinandrium narrow, sometimes with free wing-like projections. Stigma ventral, oblong to elliptic, basally deeply concave. Rostellum erect, triangular to ligulate, acute to subblunt, usually exceeding the anther apex, built of few cell layers. The apex of the rostellum, which is covered by a cuticula, forms a single, minute, semifluid viscidium (Fig. 2).

\section{LIST OF MICROSTYLIS SPECIES}

1. Microstylis cylindrostachya Rchb.f., Walp. Ann. Bot. Syst. 6: 207. 1861.

2. Microstylis macrostaychya (Lex. in Llave \& Lex.) Lindl., Gen. et Sp. Orchid. 21. 1830.

3. Microstylis monophyllos (L.) Lindl., Gen. et Sp. Orchid. Pl.: 19. 1830.

3a. Microstylis monophyllos (L.) Sw. subsp. brachypoda (A. Gray.) Szlach. \& Marg. comb. \& stat. nov. Basionym: Microstylis brachypoda A. Gray, Ann. Lyc. N. York 3: 228. 1835.

4. Microstylis montana Rothr., Rept. Bot. Wheeler, Surv. 6: 264.1878.

5. Microstylis muscifera (Lindl.) Ridl., J. Linn. Soc. Bot. 24: 333.1888.

6. Microstylis pringlei S. Watson, Proc. Am. Acad. Arts 23: 282.1888.

7. Microstylis salazarii (Catling) Szlach. \& Marg. comb. nov.

Basionym: Malaxis salazarii Catling, Orquidea (Mexico) 12 (1): 98. 1990.

8. Microstylis simillima Rchb.f., Beitr. Orch. Centr. Am. 101.1866.

9. Microstylis streptopetala B.L.Rob. \& Greenm., Proc. Am. Acad. Arts 32: 36. 1896.

10. Microstylis tamayoana (Garay \& Kittr.) Szlach. \& Marg. comb. nov.

Basionym: Malaxis tamayoana Garay \& Kittr., McVaugh, Fl. Novo-Galiciana 16: 200-202; figs. 57$-58.1985$.
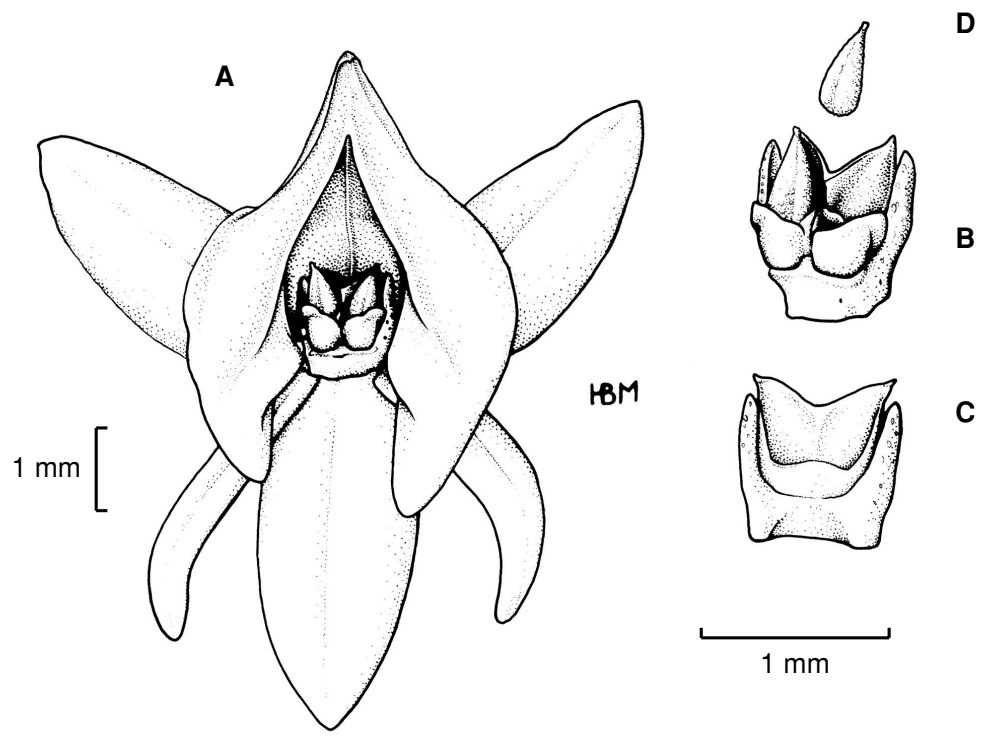

$1 \mathrm{~mm}$

Fig. 1. Malaxis spicata Sol. ex Sw.: A - flower; B - gynostemium, front view; C - gynostemium, back view; D - pollinia (drawing from: holotype - Sollander sn - BM). 


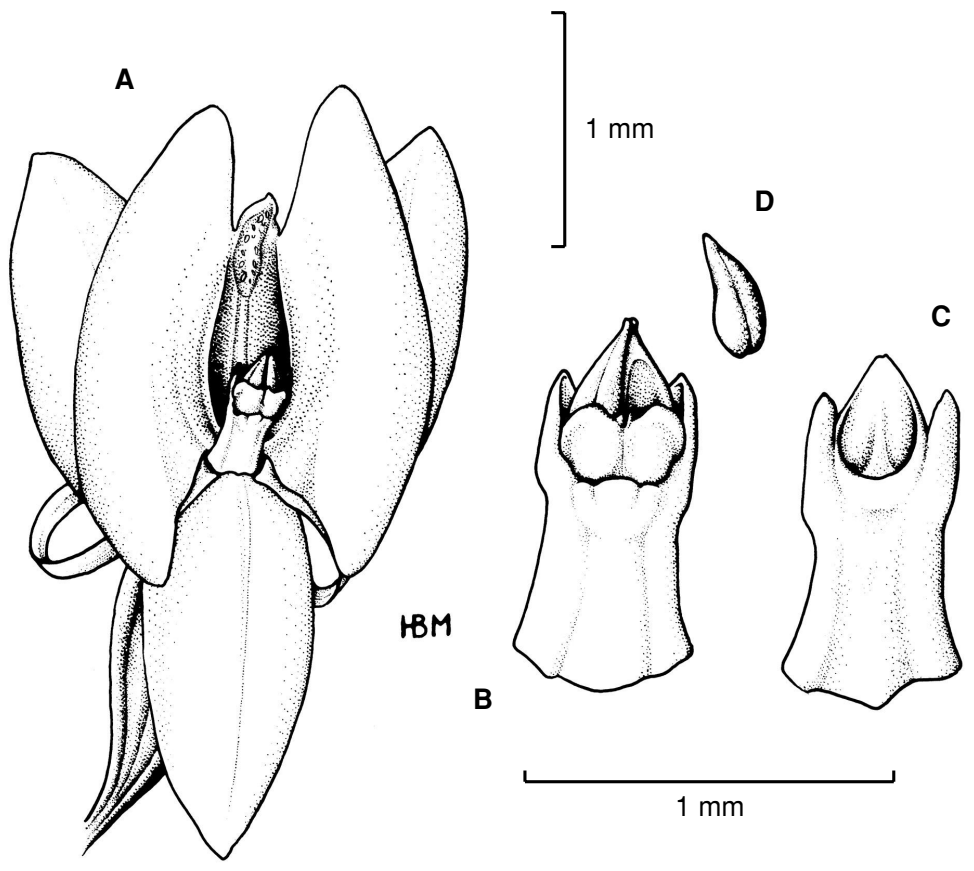

Fig. 2. Microstylis unifolia (Michx.) Britton: A - flower; B - gynostemium, front view; C - gynostemium, back view; D - pollinia (drawing from: lectotype - Michaux sn - P).

11. Microstylis tepicana (Ames) Szlach. \& Marg. comb. nov. Basionym: Malaxis tepicana Ames, Proc. Biol. Soc. Wash. 35: 83. 1922.

12. Microstylis unifolia (Michx.) Britton, Stern. \& Pogg., Prelim. Cat. Anthoph. \& Pterid. N. York 51.1888. GENERITYPE.

13. Microstylis yunnanensis Schltr., Notes Bot. Gard. Edin. 5: 109. 1912.

\section{ACKNOWLEDGMENTS}

This study was financed by KBN (Polish Committee for Scientific Research) grant No. 3P04C-082-24.

\section{LITERATURE CITED}

BRITTON N., BROWN A. Illustrated Flora of the Northern United States, Canada

and the British possessions. 2 ed. New York. 570. 1913.

COMBER J.B. 1990. Orchids of Java. 141-159. Royal Botanic Gardens, Kew.

COMBER J.B. 2001. Orchids of Sumatra. 170-185. Natural History Publications (Borneo).

EATON A. 1822. Manual of botany for the northern States. 353., 3. ed. Albany.

GREUTER W., MCNEILLI J., BARRIE F.R., BURDET H.M., DEMOULIN V., FILGUEIRAS T.S., NICOLSON D.H., SILVA P.C., SKOG J., TREHANE P., TURLAND N.J., HAWKSWORTH D.L. 2000. International code of botanical nomenclature (Saint Louis Code) adopted by the Sixteenth International Botanical Congress, St Louis, Missouri, July-August 1999. Regnum Veg. 138; xviii + 474 pp.
HILL H.D., Blaxell D.F. 1985. Notes on the genus Malaxis Sol. ex Sw., including a new record for Australia. Orchadian 8 (4): 80-82.

HOLTTUM R.E. 1957. Orchid of Malaya. 2 ed. 759 pp. Singapore.

KUNTZE O. 1891. Revisio Generum Plantarum. 2: 665-674.

MARGOŃSKA H.B. 2006. Seidenforchis - a new genus of Malaxidinae (Orchidaceae), from Thailand. Acta Soc. Bot. Pol. (in press)

MARGONSKA H.B., SZLACHETKO D.L. 2001. Saurolophorkis Marg. \& Szlach., gen. nov. (Orchidaceae, Malaxidinae, a new orchid genus from New Guinea. Pol. Bot. J. 46 (1): 7-9.

NUTTALL T. 1818. The genera of North American plants. 2. Philadelphia. 254 pp.

RAFINESQUE C.S. 1808. Medical Repository. N. York. Hex. 2, 5: 352 .

RIDLEY H.N. 1888. A revision of the genera Microstylis and Malaxis. J. Linn. Soc. 24: 308-351.

SEIDENFADEN G. 1978. Orchid Genera in Thailand. 7., Oberonia Lindl.\& Malaxis Sol. ex Sw. Dansk Bot. Arkiv 31 (1): 1-94.

SEIDENFADEN G. 1992. The Orchids of Indochina. Opera Bot. 114: 146-150.

SEIDENFADEN G., WOOD J.J. 1992. The Orchids of Peninsular Malaysia and Singapore. 218-226. Olsen \& Olsen.

SWARTZ O. 1788. Nova Genera et Species Plantarum seu Prodromus. Orchidaceae: 118-126. Upsala \& Abo.

SZLACHETKO D.L. 1995. Systema Orchidalium. Fragm. Flor. et Geobot., Suppl. 3: 123-133.

SZLACHETKO D.L., MARGOŃSKA H.B. 1999. Redefinition of the genus Pseudoliparis Finet, with descriptions of new species. Adansonia, Ser.3., 21: 275-282.

SZLACHETKO D.L., MARGOŃSKA H.B. 2002. Gynostemia Orchidalium. 2. Acta Bot. Fen. 173: 78-81.

WOOD J.J., CRIBB P.J. 1994. A check-list of the Orchids of Borneo. 97-104. Royal Botanic Gardens, Kew. 